\title{
Critical thinking: concept analysis from the perspective of Rodger's evolutionary method of concept analysis
}

\author{
Fábio da Costa Carbogim ${ }^{1}$ \\ Larissa Bertacchini de Oliveira² \\ Vilanice Alves de Araújo Püschel ${ }^{3}$
}

\begin{abstract}
Objective: to analyze the concept of critical thinking (CT) in Rodger's evolutionary perspective. Method: documentary research undertaken in the Cinahl, Lilacs, Bdenf and Dedalus databases, using the keywords of 'critical thinking' and 'Nursing', without limitation based on year of publication. The data were analyzed in accordance with the stages of Rodger's conceptual model. The following were included: books and articles in full, published in Portuguese, English or Spanish, which addressed CT in the teaching and practice of Nursing; articles which did not address aspects related to the concept of CT were excluded. Results: the sample was made up of 42 works. As a substitute term, emphasis is placed on 'analytical thinking', and, as a related factor, decisionmaking. In order, the most frequent preceding and consequent attributes were: ability to analyze, training of the student nurse, and clinical decision-making. As the implications of $\mathrm{CT}$, emphasis is placed on achieving effective results in care for the patient, family and community. Conclusion: CT is a cognitive skill which involves analysis, logical reasoning and clinical judgment, geared towards the resolution of problems, and standing out in the training and practice of the nurse with a view to accurate clinical decision-making and the achieving of effective results.
\end{abstract}

Descriptors: Nursing; Thinking; Concept Formation; Nursing Process; Decision Making.

\footnotetext{
Doctoral Student, Escola de Enfermagem, Universidade de São Paulo, São Paulo, SP, Brazil. Assistant Professor, Departamento de Enfermagem Aplicada, Universidade Federal de Juíz de Fora, Juiz de Fora, MG, Brazil.

2 Doctoral Student, Escola de Enfermagem, Universidade de São Paulo, São Paulo, SP, Brazil. RN, Instituto do Coração, Hospital das Clínicas, Faculdade de Medicina, Universidade de São Paulo, São Paulo, SP, Brazil.

${ }^{3}$ PhD, Associate Professor, Escola de Enfermagem, Universidade de São Paulo, São Paulo, SP, Brazil.
}

\section{How to cite this article}

Carbogim FC, Oliveira LB, Püschel VAA. Critical thinking: concept analysis from the perspective of Rodger's evolutionary method of concept analysis. Rev. Latino-Am. Enfermagem. 2016;24:e2785. [Access Available in: DOI: http://dx.doi.org/10.1590/1518-8345.1191.2785. month 


\section{Introduction}

The concept of critical thinking (CT) has, over the last two decades, been one of the most discussed in the area of the teaching and clinical practice of Nursing(1-2). However, as a transversal domain, it extends to the various areas in which people work, from the most simple and routine, to the most complex and painstaking professional and academic tasks( ${ }^{(3-4)}$.

The literature on CT has its roots in two academic disciplines: philosophy and psychology(4-6). However, one can also observe a third axis in the field of education $^{(4,6)}$. In philosophy, one seeks to define the hypothetical critical thinker based on her qualities and characteristics ${ }^{(4,6)}$, while psychology seeks to describe the critical thinker based on her skills or actions ${ }^{(4)}$. In the ambit of education, there is a focus on the teaching and assessment of CT skills. As a result, there is a lack of consensus regarding the concept of CT in the literature, especially in the area of Nursing, which is influenced by these three axes.

In the area of healthcare - including nursing - the aging of the population, the increase in the complexity of illnesses and consequently in the care required, as well as the demand for services, require a professional with skills in $\mathrm{CT}$, problem resolution and decisionmaking, and who is capable of appropriately accessing information, leading to safe, efficacious clinical practice which is based in scientific evidence ${ }^{(3,7-8)}$.

$\mathrm{CT}$ is an essential tool for the teaching and care practice of the nurse, and must not be confused with intelligence, but, rather, understood as a skill which can be learned(9-10). This being the case, because of the importance of the need to train professional nurses able to think critically, the Red Iberoamericana de Investigación en Educación en Enfermería (RIIEE) addressed this issue in its multicentric investigation project ${ }^{(11)}$ carried out in 16 countries in Ibero-America, this study being part of this investigation.

Researching CT in conjunction with an international investigation network ${ }^{(11)}$ encouraged the authors to undertake the present work, as, as has been observed in the literature in Nursing ${ }^{(4,7,11-12)}$, the term CT presents variations, causing frequent disagreements, which indicates the need for refining and clarifying the concept. As a result, this study's objective is to analyze the concept of critical thinking in the teaching and clinical practice of Nursing, in the perspective of Rodger's evolutionary model of concept analysis ${ }^{(13)}$. The rationale for this study of the conceptual analysis of $\mathrm{CT}$, specific to Nursing, is that it promotes clarification for future studies in the ambit of these professionals' academic and clinical practice.

\section{Method}

A documentary study ${ }^{(14)}$ based on the evolutionary model of concept analysis proposed by Rodgers ${ }^{(13)}$. This model understands the concept as a reverberation of the phenomena, which are dynamic, as they change over time and have a direct relationship with the context of their use. They have an inductive, nonsequential and descriptive character, indicating systematic rigor, considering a definition which presents conceptual problems $^{(13)}$.

The process of analysis of the concept took place based on its substitute terms and related concepts, attributes, antecedents, and implications, and involves five stages ${ }^{(13)}$. In the first stage, the concept of interest was identified(13), in the present study, CT, including the expressions and substitute terms used for the concept in the literature.

In the second stage, undertaken in February 2015, the authors proceeded to consult with the Cinahl, Lilacs and Bdenf databases ${ }^{(13)}$, due to these being considered to be important in the context of the Brazilian and foreign scientific production, in the ambit of Nursing. Use was also made of the Dedalus database, for obtaining textbooks of Nursing from the Collective Catalog of the Libraries of the University of São Paulo. As a specific descriptor for CT was not found, the same was inserted in the search as a keyword, along with the descriptor 'Nursing'. The works were identified using the search strategy of critical thinking AND nursing and its variations for Portuguese and Spanish, without limiting the search by year of publication. A total of 529 works were located in the databases mentioned.

In the third stage, for collection of the relevant data, identification of the attributes, and the contextual basis of the concept ${ }^{(13)}$, the following were defined as inclusion criteria: textbooks and articles of Nursing published in full, published in English, Portuguese or Spanish, and which addressed CT in the teaching and clinical practice of Nursing. The following were defined as exclusion criteria: duplicated studies and those which did not address aspects related to the concept of CT.

In the fourth stage, for analysis of the data and identification of their characteristics ${ }^{(13)}$, firstly the reading of the titles of the works selected in the second stage was undertaken, based in the criteria of inclusion and exclusion. A total of 481 works was obtained. Next, the abstracts were read in order to select those which addressed the issue of CT in the context of Nursing. Based on this refinement, 47 works were selected, including both books and articles. Following individual and thorough reading of each text in full, a sample of 42 was defined for analysis, including books and articles. 
At this point, the authors proceeded to reading based on the guiding questions: what are the characteristics/ attributes of CT? What are the conditions/means which viabilize $\mathrm{CT}$ ? What are the consequences of $\mathrm{CT}$ ? In this stage, through an inductive process, theattributes, antecedents and consequence of the concept, which appeared with the greatest frequency, were identified in the texts. The organization of the stages of the phenomenon analyzed took place through typing, with each characteristic being listed separately, according to the number of authors who addressed it. The data were organized in a Microsoft Office Excel ${ }^{\circledR} 2013$ spreadsheet.

In the fifth stage, implications or hypotheses for continuity of the development of the concept were listed ${ }^{(13)}$.

\section{Results}

Of the 42 works selected for analysis, eight were text books and 34 were articles, with 28 (66.6\%) published in English, 12 (28.6\%) in Portuguese, and two $(4.8 \%)$ in Spanish. Of these, the oldest dated from 1997, and the most recent from September 2014: items were included by title, authors, and cataloguing data of the book or periodical (Figure 1). The results below were organized inductively, based on what Rodgers ${ }^{(13)}$ proposes as substitute terms, the attributes, antecedents and consequences, and implications/ hypotheses of the concept.

\begin{tabular}{|c|c|c|}
\hline Title & Authors & $\begin{array}{c}\text { Book/Periodical (year, volume, } \\
\text { number and page) }\end{array}$ \\
\hline $\begin{array}{l}\text { Elementos estruturais do pensamento crítico de enfermeiros atuantes } \\
\text { em emergências (Structural elements of the critical thinking of nurses } \\
\text { working in emergencies) }\end{array}$ & $\begin{array}{l}\text { Crossetti MG, } \\
\text { Bittencourt GK, Lima } \\
\text { AA, GóesMG, Saurin } \\
\text { G. }\end{array}$ & $\begin{array}{l}\text { RevGauchaEnferm. } 2014 \\
\text { Sep;35(3):55-60. }\end{array}$ \\
\hline $\begin{array}{l}\text { Exploring the relationships between teaching, approaches to learning } \\
\text { and } \\
\text { critical thinking in a problem-based learning foundation nursing course. }\end{array}$ & $\begin{array}{l}\text { Martyn J, TerwijnR, } \\
\text { Kek MYCA, Huijser H. }\end{array}$ & $\begin{array}{l}\text { Nurse EducToday. } 2014 \\
\text { May;34(5):829-35. }\end{array}$ \\
\hline $\begin{array}{l}\text { O desenvolvimento da competência crítica e reflexiva no contexto } \\
\text { de um currículo integrado (The development of critical and reflexive } \\
\text { competence in the context of an integrated curriculum). }\end{array}$ & $\begin{array}{l}\text { Alves E, Oliveira MAC } \\
\text { (org). }\end{array}$ & INESCO: Londrina, 2014. 240p. \\
\hline $\begin{array}{l}\text { Enseñanza y Aprendizaje del Pensamiento Reflexivo y Crítico en } \\
\text { Estudiantes de Enfermería en Iberoamérica (The Teaching and Learning } \\
\text { of Reflexive and Critical Thinking in Students of Nursing in Ibero- } \\
\text { America) }\end{array}$ & Becerril LC, et al. & México: Cigome, 2014. v. 1. 333p. \\
\hline $\begin{array}{l}\text { Critical Thinking, Clinical Reasoning and Clinical Judgment: a practical } \\
\text { approach. }\end{array}$ & Alfaro-LeFevre R. & $\begin{array}{l}\text { 5th ed. Elsevier: St. Louis, MO, } 2013 . \\
\text { 311p. }\end{array}$ \\
\hline A systematic review of critical thinking in nursing education. & Chan ZCY. & $\begin{array}{l}\text { Nurse EducToday. } 2013 \\
\text { Mar;33(3):236-40. }\end{array}$ \\
\hline Critical thinking and creativity in nursing: Learners' perspectives. & Chan ZCY. & $\begin{array}{l}\text { Nurse EducToday. } 2013 \\
\text { May;33(5):558-63. }\end{array}$ \\
\hline $\begin{array}{l}\text { Habilidades de pensamento crítico no processo diagnóstico em } \\
\text { enfermagem (Critical thinking skills in the diagnostic process in nursing). }\end{array}$ & $\begin{array}{l}\text { Bittencourt GK, } \\
\text { Crossetti Mda G. }\end{array}$ & $\begin{array}{l}\text { RevEscEnferm USP. } 2013 \\
\text { Apr;47(2):341-7. }\end{array}$ \\
\hline $\begin{array}{l}\text { Effect of caring behavior on disposition toward critical thinking of nursing } \\
\text { students. }\end{array}$ & $\begin{array}{l}\text { Pai HC, Eng CJ, Ko } \\
\text { HL. }\end{array}$ & $\begin{array}{l}\text { J Prof Nurs. } 2013 \text { Nov- } \\
\text { Dec;29(6):423-9. }\end{array}$ \\
\hline $\begin{array}{l}\text { Modelo teórico de pensamento crítico no processo diagnóstico em } \\
\text { enfermagem (The theoretical model of critical thinking in the diagnostic } \\
\text { process in nursing). }\end{array}$ & $\begin{array}{l}\text { Bittencourt GKGD, } \\
\text { Crossetti MGO. }\end{array}$ & $\begin{array}{l}\text { Online braz j nurs. Oct } 2012 \text { Oct; } 11 \\
\text { Suppl 1: 563-7. }\end{array}$ \\
\hline $\begin{array}{l}\text { Critical thinking in clinical nurse education: Application of Paul's model } \\
\text { of critical } \\
\text { Thinking. }\end{array}$ & Sullivan EA. & $\begin{array}{l}\text { Nurse EducPract. } \\
2012 \text { Nov;12(6):322-7. }\end{array}$ \\
\hline $\begin{array}{l}\text { Case studies combined with or without concept maps improve critical } \\
\text { thinking in hospital-based nurses: A randomized-controlled trial. }\end{array}$ & $\begin{array}{l}\text { Huang YC, Chen } \mathrm{HH} \text {, } \\
\text { Yeh ML, Chung YC. }\end{array}$ & $\begin{array}{l}\text { Int J Nurs Stud. } 2012 \text { Jun;49(6):747- } \\
54 .\end{array}$ \\
\hline
\end{tabular}




\begin{tabular}{|c|c|c|}
\hline $\begin{array}{l}\text { Pensamento Crítico para o Alcance de Resultados Positivos em Saúde } \\
\text { (Critical Thinking for Achieving Positive Results in Health). }\end{array}$ & Lunney M. & Porto Alegre: Artmed, 2011, 353p. \\
\hline $\begin{array}{l}\text { Relationships between critical thinking ability and nursing competence } \\
\text { inclinical nurses. }\end{array}$ & $\begin{array}{l}\text { Chang MJ, Chang } \\
\text { YJ, KuoSH,Yang YH, } \\
\text { Chou FH }\end{array}$ & $\begin{array}{l}\text { J ClinNurs. } 2011 \text { Nov;20(21-22):3224- } \\
32 .\end{array}$ \\
\hline $\begin{array}{l}\text { Raciocínio clínico e pensamento crítico (Clinical reasoning and critical } \\
\text { thinking). }\end{array}$ & $\begin{array}{l}\text { Cerullo JASB, Cruz } \\
\text { DALM. }\end{array}$ & $\begin{array}{l}\text { Rev. Latino-Am. Enfermagem jan-fev } \\
\text { 2010; 18(1):[06 telas]. }\end{array}$ \\
\hline $\begin{array}{l}\text { Patrones de pensamiento crítico en alumnos post exposición a un } \\
\text { modelo de enseñanza integrado a enfermeira. (Patterns of critical } \\
\text { thinking in students following exposure to a model of teaching integrated } \\
\text { with the nurse) (OBS: ENFERMERA, NÃO ENFERMEIRA) }\end{array}$ & Isaacs LG. & InvestEducEnferm2010;28(3):263-69. \\
\hline $\begin{array}{l}\text { Estratégias de ensino das habilidades do pensamento crítico na } \\
\text { enfermagem (Strategies for teaching the skills of critical thinking in } \\
\text { nursing). }\end{array}$ & $\begin{array}{l}\text { Crossetti MG, } \\
\text { Bittencourt GK, } \\
\text { Schaurich D, Tanccini } \\
\text { T, Antunes M. }\end{array}$ & $\begin{array}{l}\text { RevGauchaEnferm. } 2009 \\
\text { Dec;30(4):732-41. }\end{array}$ \\
\hline Nurse educators' critical thinking dispositions and research utilization. & $\begin{array}{l}\text { Profetto-McGrath J, } \\
\text { Smith KB, Hugo K, } \\
\text { Patel A, Dussault B. }\end{array}$ & $\begin{array}{l}\text { Nurse EducPract. } 2009 \text { May;9(3):199- } \\
208\end{array}$ \\
\hline $\begin{array}{l}\text { Facilitating critical thinking within the nursing process framework: a } \\
\text { literature review. }\end{array}$ & Chabeli MM. & $\begin{array}{l}\text { Health SA Gesondheid2007;12 (4):69- } \\
90, .\end{array}$ \\
\hline Critical thinking dispositions in baccalaureate nursing students. & $\begin{array}{l}\text { Shin KR, Lee JH, Ha } \\
\text { JY, Kim KH. }\end{array}$ & J AdvNurs. 2006 Oct;56(2):182-9. \\
\hline Critical Thinking: Back to Square Two & $\begin{array}{l}\text { Walsh CM, } \\
\text { Seldomridge LA. }\end{array}$ & J Nurs Educ. 2006 Jun;45(6):212-9. \\
\hline $\begin{array}{l}\text { Estratégias de ensino na enfermagem: enfoque no cuidado e no } \\
\text { pensamento crítico (Teaching strategies in nursing: a focus on the care } \\
\text { and on critical thinking). }\end{array}$ & Waldow VR. & Rio de Janeiro: Vozes, 2005, 136p. \\
\hline $\begin{array}{l}\text { Critical thinking in nursing education and practice as defined in the } \\
\text { literature. }\end{array}$ & Turner P. & $\begin{array}{l}\text { NursEducPerspect. } 2005 \text { Sep- } \\
\text { Oct;26(5):272-7. }\end{array}$ \\
\hline $\begin{array}{l}\text { Critical Thinking in Nursing: An Integrated } \\
\text { Review. }\end{array}$ & Brunt BA. & $\begin{array}{l}\text { J ContinEducNurs. } 2005 \text { Mar- } \\
\text { Apr;36(2):60-66. }\end{array}$ \\
\hline Conceptions of Critical Thinking Held by Nurse Educators. & Walthew P. & J Nurs Educ. 2004 Sep;43(9):408-11 \\
\hline $\begin{array}{l}\text { Análise Conceitual e Pensamento Crítico: uma relação complementar } \\
\text { na enfermagem (Conceptual Analysis and Critical Thinking: a } \\
\text { complementary relationship in nursing). }\end{array}$ & $\begin{array}{l}\text { Enders BC, Brito RS, } \\
\text { Monteiro Al. }\end{array}$ & $\begin{array}{l}\text { Rev Gaúcha Enferm. } 2004 \\
\text { Dez;25(3):295-305. }\end{array}$ \\
\hline $\begin{array}{l}\text { Pensamento crítico e diagnósticos de enfermagem estudos de caso } \\
\text { e análises (Critical thinking and nursing diagnoses - case studies and } \\
\text { analyses). }\end{array}$ & Lunney M, Marques R. & Porto Alegre: Artmed, 2004, 384p. \\
\hline Medical-surgical nursing: critical thinking in client care. & $\begin{array}{l}\text { LeMone C, Burke } \\
\text { KM. }\end{array}$ & $\begin{array}{l}\text { 3th ed Upper Saddle River, N.J. : } \\
\text { Pearson Prentice Hall, 2004, 78p. }\end{array}$ \\
\hline Teaching and Measuring Critical Thinking. & Staib S. & $\begin{array}{l}\text { J Nurs Educ. } 2003 \text { Nov;42(11):498- } \\
508 .\end{array}$ \\
\hline $\begin{array}{l}\text { Critical Thinking and Clinical Decision Making In Critical Care Nursing: } \\
\text { a pilot study. }\end{array}$ & $\begin{array}{l}\text { Hicks FD, Merritt SL, } \\
\text { Elstein AS. }\end{array}$ & $\begin{array}{l}\text { Heart Lung. } 2003 \text { May- } \\
\text { Jun;32(3):169-80. }\end{array}$ \\
\hline Critical thinking at the bedside: a practical perspective. & Edwards C & $\begin{array}{l}\text { Br J Nurs. } 2003 \text { Oct 23-Nov } \\
\text { 12;12(19):1142-9. }\end{array}$ \\
\hline Critical thinking and accuracy of nurses' diagnoses. part II. & Lunney M. & $\begin{array}{l}\text { Rev Esc Enferm USP. } 2003 \\
\text { Sep;37(3):106-12. }\end{array}$ \\
\hline
\end{tabular}




\begin{tabular}{|c|c|c|}
\hline Critical thinking and accuracy of nurses' diagnoses. part I. & Lunney M. & $\begin{array}{l}\text { RevEscEnferm USP. } 2003 \\
\text { Jun;37(2):17-24. }\end{array}$ \\
\hline $\begin{array}{l}\text { Critical thinking in nursing education: } \\
\text { Literaturereview. }\end{array}$ & $\begin{array}{l}\text { Simpson E, Courtney } \\
\text { M. }\end{array}$ & Int J NursPract.2002 Apr;8(2):89-98. \\
\hline $\begin{array}{l}\text { Desenvolvendo o pensamento crítico em alunos de enfermagem: uma } \\
\text { experiência através da metodologia da problematização (Developing } \\
\text { critical thinking in students of nursing: an experiment using the } \\
\text { methodology of problematization). }\end{array}$ & Tacla MTGM & Goiânia: Goiânia AB, 2002, 191p. \\
\hline The Holism in Critical Thinking. & Thurmond VA. & J HolistNurs. 2001 Dec;19(4):375-89. \\
\hline $\begin{array}{l}\text { The Development of Critical Thinking among Students in Baccalaureate } \\
\text { Nursing Education. }\end{array}$ & Redding DA. & HolistNursPract. 2001 Jul;15(4):57-64. \\
\hline $\begin{array}{l}\text { Assessing Critical Thinking in Baccalaureate Nursing Students: a } \\
\text { longitudinal study. }\end{array}$ & $\begin{array}{l}\text { Beckie TM, Lowry LW, } \\
\text { Barnett S. }\end{array}$ & $\begin{array}{l}\text { HolistNursPract. } 2001 \text { Apr;15(3):18- } \\
26 .\end{array}$ \\
\hline $\begin{array}{l}\text { Pensamento Crítico: um enfoque na educação em enfermagem (Critical } \\
\text { Thinking: a focus on education in nursing). }\end{array}$ & Lima MA, Cassiani SH. & $\begin{array}{l}\text { Rev Lat Am Enfermagem. } 2000 \\
\text { Jan;8(1):23-30. }\end{array}$ \\
\hline $\begin{array}{l}\text { Critical thinking as an outcome of nursing education. What is it? Why is } \\
\text { it important to nursing practice? }\end{array}$ & Daly WM. & J AdvNurs. 1998 Aug;28(2):323-31. \\
\hline $\begin{array}{l}\text { Critical Thinking Skills and dispositions of Baccalaureate Nursing } \\
\text { Students: a conceptual model for evaluation. }\end{array}$ & Colucciello ML. & $\begin{array}{l}\text { J Prof Nurs.1997 Jul- } \\
\text { Aug;13(4):236-45. }\end{array}$ \\
\hline $\begin{array}{l}\text { A Proposed Framework for Teaching and Evaluating Critical Thinking in } \\
\text { Nursing. }\end{array}$ & Dexter $\mathrm{P}$, et al. & $\begin{array}{l}\text { J Prof Nurs.1997 May- } \\
\text { Jun;13(3):160-7. }\end{array}$ \\
\hline
\end{tabular}

Figure 1 - Works included for analysis, by title, authors and book or periodical. São Paulo, State of São Paulo (SP), Brazil, 2015.

The identification of the substitute terms represents the first approximation with the concept to be analyzed(13) $^{(13}$ for understanding the origin, development, functions and interconnections of a concept with other similar words or expressions. The substitute terms for CT identified were: analytical thinking ${ }^{(15)}(14.3 \%)$, critical-creative thinking ${ }^{(16)}(12 \%)$, nonlinear thinking ${ }^{(17)}$ (9.5\%) and critical-holistic thinking(16) $(9.5 \%)$.

Differently from the substitute terms, the concepts related to $\mathrm{CT}$ (Table 1 ) have a link and closeness to it, but are not synonymous with it.

Table 1 - Factors/concepts related to Critical Thinking, by number of works analyzed. São Paulo, SP, Brazil, 2015

\begin{tabular}{lcc}
\hline \multicolumn{1}{c}{ Related factors/concepts } & N. of works & $\%$ \\
\hline Decision-making & 23 & 54.0 \\
Clinical judgment & 22 & 52.4 \\
Reflexive thinking & 20 & 47.6 \\
Clinical reasoning & 14 & 33.3 \\
Problem resolution & 10 & 23.8 \\
Logical reasoning & 7 & 16.6
\end{tabular}

(continue...)
Table 1 - (continuation)

\begin{tabular}{lcc}
\hline \multicolumn{1}{c}{ Related factors/concepts } & N. of works & $\%$ \\
\hline Scientific method & 7 & 16.6 \\
Critical reflection & 7 & 16.6 \\
Diagnostic judgment & 7 & 16.6 \\
Diagnostic reasoning & 5 & 12.0 \\
Critical analysis & 4 & 9.5 \\
Critical assessment & 4 & 9.5 \\
Interpretive thinking & 3 & 7.1 \\
Socratic thinking & 3 & 7.1 \\
Complex reasoning & 3 & 7.1 \\
\hline
\end{tabular}

CT is characterized by higher-level thinking, which involves knowledge, experiences, dispositions (attitudes or habits of mind) and intellectual abilities. These essential characteristics, or attributes, were identified in the empirical material for analysis as skills and dispositions for $\mathrm{CT}$, and are presented in Table 2. 
Table 2 -Attributes (skills and dispositions) of the concept of Critical Thinking, by number of works analyzed. São Paulo, SP, Brazil, 2015

\begin{tabular}{|c|c|c|}
\hline Attributes & N. of works & $\%$ \\
\hline \multicolumn{3}{|l|}{ Skills } \\
\hline Analysis & 39 & 92.8 \\
\hline Assessment & 34 & 80.4 \\
\hline Inference & 26 & 62.0 \\
\hline Rational examination & 23 & 54.7 \\
\hline Interpretation & 23 & 54.7 \\
\hline Self-regulation & 19 & 45.2 \\
\hline Reflection & 18 & 42.8 \\
\hline Judgment & 17 & 40.5 \\
\hline Deduction & 14 & 33.3 \\
\hline Application of standards & 10 & 23.8 \\
\hline Questioning & 9 & 21.4 \\
\hline Summarizing & 9 & 21.4 \\
\hline \multicolumn{3}{|l|}{ Dispositions } \\
\hline Open-mindedness & 24 & 57.1 \\
\hline Curiosity & 23 & 54.7 \\
\hline Honesty in facing personal prejudices & 17 & 40.5 \\
\hline Systematicity & 16 & 38.0 \\
\hline
\end{tabular}

Table 2 - (continuation)

\begin{tabular}{lcc}
\multicolumn{1}{c}{ Attributes } & N. of works & $\%$ \\
\hline Clarity regarding questions and ideas & 16 & 38.0 \\
Self-regulated judgment & 16 & 38.0 \\
Actively searching for truth & 15 & 35.7 \\
Maturity & 13 & 31.0 \\
Metacognition & 12 & 28.6 \\
Focus on accurate results & 12 & 28.6 \\
Trusting in reason & 12 & 28.6 \\
Seeking information & 11 & 26.2 \\
Prudence in judgments & 11 & 26.2 \\
Analyticity & 10 & 23.8 \\
$\begin{array}{l}\text { Perseverance } \\
\text { Assessment of the credibility } \\
\text { evidence }\end{array}$ & 10 & 23.8 \\
\hline
\end{tabular}

The antecedents, like the consequences of a concept, are conditioned to a contextual basis, in this case, the concept of CT in Nursing. In addition to this, they are related to the situational, temporal, sociocultural and course-related contexts of the profession at the present time ${ }^{(13)}$. The antecedents are considered the events, situations or phenomena which precede the concept investigated, while the consequences are situations which result from the occurrence of the concept in question (Table 3).

Table 3 - Antecedents and Consequences of the concept of Critical Thinking by number of works analyzed. São Paulo, SP, Brazil, 2015

\begin{tabular}{|c|c|c|}
\hline Antecedents and Consequences & N. of works & $\%$ \\
\hline \multicolumn{3}{|l|}{ Antecedents } \\
\hline Teaching in Nursing/Training of the Student of Nursing & 25 & 59.5 \\
\hline Teaching Policies/Curricular Guidelines of Nursing courses & 23 & 54.7 \\
\hline The need for better results in clinical practice & 19 & 45.2 \\
\hline Scientific and Technological Advances/Complexity of the health systems & 18 & 42.8 \\
\hline Cognitive, attitudinal and instrumental development of the nurse & 8 & 19.0 \\
\hline The need for decision-making/Management in health & 8 & 19.0 \\
\hline Practice Based in Scientific Evidence & 7 & 16.6 \\
\hline Safety in the care/quality of the health services & 6 & 14.3 \\
\hline Requirements of the job market & 5 & 12.0 \\
\hline Reflection, analysis and criticism & 7 & 16.6 \\
\hline Actions based in relevant evidence & 5 & 12.0 \\
\hline Summary & 9 & 21.4 \\
\hline Consequences & & \\
\hline
\end{tabular}




\begin{tabular}{|c|c|c|}
\hline Antecedents and Consequences & N. of works & $\%$ \\
\hline Clinical decision-making & 37 & 88.0 \\
\hline Clinical judgment & 23 & 54.8 \\
\hline Clinical reasoning & 22 & 52.4 \\
\hline Organization of the Nursing Process & 18 & 42.8 \\
\hline Problem resolution & 15 & 35.7 \\
\hline Better results in the practice of teaching & 11 & 26.2 \\
\hline Diagnostic accuracy & 9 & 21.4 \\
\hline Positive results in the attendance of the patient & 8 & 19.0 \\
\hline Reflection, analysis and criticism & 7 & 16.6 \\
\hline Actions based in relevant evidence & 5 & 12.0 \\
\hline
\end{tabular}

The implications and hypotheses represent, respectively, the results and possibilities to be achieved ${ }^{(13)}$ by a critical thinker in the ambit of Nursing and are important aspects for the development of the concept over time ${ }^{(13)}$. In accordance with the frequency as certained in the works, the implications and hypotheses are listed in Table 4.

Table 4 - Implications and hypotheses of the concept of Critical Thinking by number of works analyzed. São Paulo, SP, Brazil, 2015

\begin{tabular}{|c|c|c|}
\hline Implications and Hypotheses & N. of works & $\%$ \\
\hline Achieving effective results in care for the patient, family and community & 15 & 35.7 \\
\hline Safety and quality of the care & 14 & 33.3 \\
\hline Professional growth and satisfaction & 13 & 31.0 \\
\hline Autonomy in the work process & 13 & 31.0 \\
\hline Achieving effective results in the teaching and in the routine of the nursing practice & 10 & 23.8 \\
\hline Citizens with critical-creative spirit in the social milieu which they are part of & 8 & 19.0 \\
\hline Development of competencies and skills which go beyond the technical dimension & 8 & 19.0 \\
\hline Establishment of interdisciplinary connections & 4 & 9.5 \\
\hline
\end{tabular}

\section{Discussion}

\section{Substitute terms and related factors/concepts}

The concept of CT remains little clarified in the Nursing literature ${ }^{(1,16)}$, it being possible to identify a number of close words/expressions which are capable of representing or even explaining attributes and skills of an ideal critical thinker. In this regard, it becomes important to make it clear that substitute terms figure as expressions with meanings which are similar to the concept of CT. This aspect was discussed in one review study ${ }^{(16)}$, which indicated that clinical reasoning and CT are, often, used as synonymous terms inappropriately, as CT involves skills and attitudes which are necessary for the development of clinical reasoning.
Based on the empirical material researched, the most frequent substitute term was analytical thinking, followed by critical-creative thinking. These substitute terms, to the contrary of clinical reasoning, are synonyms, as they present a semantic interconnection with CT. As a result, when a nurse assesses a patient's health problem, observing, examining, recognizing and raising hypotheses regarding health problems, she is using analytical thinking, which can also be termed $\mathrm{CT}^{(17)}$.

On the other hand, the related factors (Table 1) have a correlation of cause or effect with the concept. For $\mathrm{CT}$, the main related factors identified are aptitudes which are necessary for undertaking the stages of the Nursing process, such as decision-making(16), clinical judgment ${ }^{(18-19)}$ and clinical reasoning(11). This 
relationship is not one of mere causality, it having been demonstrated in one study ${ }^{(20)}$ that CT skills establish a relationship between themselves and, in the same way, with the stages of the diagnostic process in Nursing. Furthermore, CT involves skills and attitudes which are fundamental for achieving excellent goals of diagnostic accuracy. It is emphasized that, as a structural element of $\mathrm{CT}$, clinical reasoning leads to clinical judgment, resulting in clinical decision-making ${ }^{(12,15,20)}$.

Another term which has been described many times coupled with $\mathrm{CT}$, nearly forming a single term, is the concept of reflexive thinking(11,15-16). The reasoning for this may be related to the fact that some authors consider reflection to be a skill of the critical thinker. Based on the hypothesis that reflection leads to critical thinking, one experimental study(21), using reflexive writing, was undertaken with 70 undergraduate students of nursing. As a result, a significant increase was observed in the CT skills among the students of the experimental group. It is, therefore, relevant to undertake studies of this issue, as they assist in the process of understanding and evolution of the concepts.

Generally speaking, the identification of the substitute terms and related factors, respectively, made it possible to broaden the list of synonymous concepts and those which are interrelated. As a result, the related concepts allow the correct application of words which contain within themselves similar philosophical presuppositions, in this case, CT. Besides this, they assist in the understanding of the application of the concept of $\mathrm{CT}$ in the context of the practice of the student or nurse, and its importance for diagnostic reasoning, clinical judgment and efficacious decision-making.

\section{Attributes of the concept of CT}

The attributes bring together a real definition of the concept, different from the nominal definition provided in dictionaries, which simply substitute one word or expression with another which is synonymous ${ }^{(13)}$. As a result, the attributes are an integral part of a concept, corresponding to its characteristics. The sum of these attributes typifies and characterizes the concept. As presented in Table 2, the attributes which qualify $\mathrm{CT}$ are made up of skills and dispositions.

It is inferred, based on these results, that in the literature there is a major influence of the Delphi Report ${ }^{(22)}$, a consensus undertaken at the beginning of the 1990 s by an interdisciplinary group of specialists in
CT from the area of the humanities, social sciences, and education, defining the essential characteristics of the ideal critical thinker. The report ${ }^{(22)}$ describes a significant proportion of the attributes identified in this study, such that these constitute the characteristics examined in most of the psychometric scales for assessing the development of CT.

In the literature analyzed, the skill mentioned most frequently for a critical thinker was "analysis"(11,15,19,22) or the ability to break something down in order to achieve an understanding of a given situation. It is believed that this skill is essential in academic and professional activity in Nursing, in that the understanding of the whole is limited to analysis of the parts, whether in the learning of a technique or in taking the patient history.

The most frequent disposition was "openmindedness"(19,22) or impartiality in assessment, overcoming preconceptions in a rational way for prudent judgment and later decision-making. However, as studies indicate ${ }^{(4,6,20)}$, these skills and dispositions must be constantly exercised, given that the human mind tends to base its decisions on patterns of the cause-andeffect type, often intuitively, without careful examination of the possible alternatives.

As a result, for the improvement in the attributes of $\mathrm{CT}$, the student or professional of Nursing must adopt a stance of seeking, in a careful, rational and active way, the improvement of the cognitive and affective aspects which are inherent to her professional and personal activities ${ }^{(21,23)}$. Based on this definition, it may be perceived that $\mathrm{CT}$ is a practical activity based on the sensible search for reason, through skills and dispositions, it being essential for the individual to have an inclination or attitude for carrying these out(20). In this process, the importance of thinking about thought (metacognition) ${ }^{(4)}$ is underlined as a necessary path to developing CT skills.

\section{Antecedents of the Concept}

Based on the categories presented in Table 3, the emphasis on the development of CT in the teaching and training of the student of Nursing is clear ${ }^{(11,16)}$, as well as the importance of the Teaching Policies, in particular the Brazilian National Curricular Guidelines (DCNs)of the undergraduate courses in Nursing ${ }^{(11,24-25)}$ as phenomena which have leveraged the discussions and highlighted the importance of training nurses in the skill of thinking critically. 
In Brazil, the $\mathrm{DCNs}^{(25)}$ bestow curricular flexibility, which viabilizes pedagogical projects geared towards specific goals or demands. As a result, there is the possibility of a teaching permeated by $\mathrm{CT}$, as it progresses towards problematizing training, linking teaching, work and community.

Another aspect also evidenced as a predecessor of CT was the seeking of better results in clinical practice $^{(14,18,22)}$ and the scientific and technological advance $^{(25-26)}$, which represent an important challenge at the time of writing, as a result of the competencies and skills which are necessary and required for the students and nurses in order to respond efficaciously to the complexity of the health systems. In this regard, studies $^{(16,19,23)}$ indicate that the rapid technological and scientific advances in the area of health, added to the rapid expansion of Nursing's body of knowledge, have required critical thinkers in the profession.

The challenge of training a nurse who is capable of acting in a way that responds to the demands of a society in constant transformation is closely related to the need for cognitive, attitudinal and instrumental development so as to seek better results in practice and in health management ${ }^{(15,23,27)}$. Besides this, the nurse's decision-making must take into account the evidence deriving from professional experience, the scientific literature and the patient's requirements, with a view to the safety and quality of the health services.

\section{Consequences of the concept of CT}

The consequences of a concept are closely related to the antecedents and must follow them ${ }^{(13)}$. As a result, the consequences presented in Table 4 are considered to be situations which result from the occurrence of CT. Hence, they trigger actions in practice and/or teaching.

The consequence identified with the highest frequency was "clinical decision-making"( $(, 23)$, followed by "clinical judgment"(11,19-20) and "clinical reasoning"(12,15). The latter two, although distinct, are fundamental in the nurse's practice and lead to clinical decisionmaking. Clinical reasoning involves mental processes applied in the activities of the nurse who, based on a judgment based on knowledge, will take an appropriate decision. In this process of intellectual action, which results in clinical intervention, CT acts as a regulator of the patterns of thinking ${ }^{(8,12)}$. It thus covers an attitude of being disposed to considering, in a conscious way, the problems which arise in the ambit of the clinical experience or of teaching.
For effective decision-making based in CT, therefore, persistent effort is required for examining any situation or supposed form of knowledge in the light of evidence which supports new conclusions in regard to $i^{(10,15)}$. One study ${ }^{(23)}$ which assessed the structural elements of CT in 20 nurses from emergency services corroborated these findings, as it emphasized the importance of CT for clinical decision-making, as well as its interconnection in the managerial, multi-professional and teaching ambits. It is relevant to emphasize that the first three consequent terms identified previously also appeared as related concepts in Table 1 , reinforcing the tenuous interconnections with $\mathrm{CT}$.

\section{Implications and hypotheses of the concept of CT}

The main implications and hypotheses listed in Table 4 are related to the nurse's care practice. As a result, the most frequent implications for a critical thinker in Nursing were: achieving effective results in care to the patient, family and community ${ }^{(19,23)}(35.7 \%)$ and safety and quality of the care ${ }^{(12,16,23)}(33.3 \%)$. Therefore, it is believed that the structural elements of CT (skills and dispositions), continuously exercised in the ambit of nursing, entail effective and safe care. It is inferred that $\mathrm{CT}$ can be a mediating instrument in the improvement of reasoning and the exercise of practice, conferring upon the nurse competences and skills for diagnosing accurately.

For this, it is important to consider CT as a process of dynamic and continuous improvement which can be learnt by the nurse. As a result, the improvement of reasoning skills, the constant search for new knowledge, the aim of solving problems and issuing judgments is required, enabling the nurse to predict, diagnose and validate the conclusions obtained, always reviewing these critically (19,26-27).

One longitudinal Australian study(28) assessed CT skills in 134 students, at two points: upon entering the undergraduate course in Nursing, and three years later, after graduating, using the Health Sciences Reasoning Test. It was concluded that the students significantly increased their CT scores after progressing through the course, principally improving their abilities in analysis and deduction. The students who had the highest scores in the test had better academic performance. These results corroborate the importance of the undergraduate course in helping the students to progress in their CT skills. 
As indicated by the works analyzed ${ }^{(15,23,26)}$, it is believed that, as she progresses in the dimensions of CT, the student or nurse can achieve greater professional satisfaction and autonomy in her work process. Among various factors analyzed in one study ${ }^{(29)}$, the nurses reported that they achieved greater professional satisfaction as they achieved greater autonomy. In this regard, CT and its structural elements are intermediary tools which lead the professional to assertiveness in her clinical actions, creating safety, autonomy and satisfaction.

\section{Conclusion}

The concept analysis, based in Rodger's evolutionary model, clarified the phenomenon and allowed a correct understanding of $\mathrm{CT}$, with implications for education and care in Nursing.

As antecedents of the concept, emphasis was placed on the need for training in critical thinking while still on the undergraduate course, with a consequent search for better results in clinical practice. This being the case, the main concepts related to CT are those which make up the stages of the Nursing Process, such as decisionmaking, clinical judgment, and clinical reasoning.

As a result, the understanding of the related factors, attributes, antecedents and consequences of CT made it possible to infer $\mathrm{CT}$ as a cognitive skill which involves a process of analysis, logical reasoning and clinical judgment, geared towards problem resolution. From this perspective, it has been emphasized in the training and care practice of the nurse, with a view to accurate clinical decision-making and to achieving effective results in the Nursing interventions for the patient, family and community.

As limitations of the study, the fact is highlighted that studies were selected from Latin American databases, with the exception of Cinahl. However, the study met the needs of the multicentric RIIEE project. As a consequence, broader studies become important, considering that the concept changes over time. Furthermore, it is necessary to develop the clarification of the concept of CT in other areas of knowledge.

\section{References}

1. Tajvidi M, Ghiyasvandian S, Salsali M. Probing concept of critical thinking in nursing education in Iran: a concept analysis. Asian Nurs Res. (Korean Soc Nurs Sci) [Internet]. 2014 [Acesso 22 Jul 2015];8(2):158-64.
Disponível em: http://www.sciencedirect.com/science/ article/pii/S1976131714000279. DOI: 10.1016/j. anr.2014.02.005. Epub 2014 May 21.

2. Azizi-Fini I, Hajibagheri A, Adib-Hajbaghery M. Critical Thinking Skills in Nursing Students: a Comparison Between Freshmen and Senior Students. Nurs Midwifery Stud. [Internet]. 2015 [Acesso 20 Jul 2015];4(1):e25721. Disponível em: http://www.ncbi. nlm.nih.gov/pmc/articles/PMC4377532/. Epub 2015 Mar 10.

3. Pitt V, Powis D, Levett-Jones T, Hunter S. The influence of critical thinking skills on performance and progression in a pre-registration nursing program. Nurse Educ Today. [Internet]. 2015 [Acesso 22 Jul 2015];35(1):125-31. Disponível em: http://www.sciencedirect.com/science/ article/pii/S026069171400269X. DOI: 10.1016/j. nedt.2014.08.006. Epub 2014 Aug 23.

4. Abrami PC, Bernard RM, Borokhovski AW, Surkes MA, Tamim R, Zhang D. Instructional interventions affecting critical thinking skills and dispositions: A stage 1 metaanalysis. Rev Educ Res. [Internet]. 2008 [Acesso 22 Jul 2015];78(4):1102-34. Disponível em: http://www. physics.emory.edu/faculty/weeks//journal/abramirer08.pdf. DOI: 10.3102/0034654308326084.

5. Bacanlıa H, Dombaycıb MA, Demirc M, Tarhand S. Quadruple Thinking: Creative Thinking. Procedia Soc Behav Sci. [Internet] . 2011 [Acesso 28 Jun 2015]; 12:53644. Disponível em: http://www.sciencedirect. com/science/article/pii/S1877042811001558. DOI: 10.1016/j.sbspro.2011.02.065

6. Almeida LS, Franco AHR. Critical thinking: Its relevance for education in a shifting society. Rev Psicol. 2011 [Acesso 28 Jun 2015];29(1):176-95. Disponível em: http://www.scielo.mec.pt/pdf/psd/v15n1/v15n1a11. pdf. DOI: http://dx.doi.org/10.15309/14psd150111

7. Papathanasiou IV, Kleisiaris CF, Fradelos EC, Kakou K, Kourkouta L. Critical thinking: the development of an essential skill for nursing students. Acta Inform Med. [Internet]. 2014 [Acesso 28 Jun 2015];22(4):283-6. Disponível em: http://www.ncbi.nlm.nih.gov/pmc/ articles/PMC4216424/. DOI: 10.5455/aim.2014.22.283286. Epub 2014 Aug 21.

8. Huang GC, Newman LR, Schwartzstein RM. Critical thinking in Health Professions Education: Summary and Consensus Statments of the Millennium Conference 2011. Teach Learn Med. [Internet]. 2014 [Acesso 28 Jun 2015];26(1):95-102. Disponível em: http://www. tandfonline.com/doi/pdf/10.1080/10401334.2013.8573 35. DOI: $10.1080 / 10401334.2013 .857335$. 
9. Ozkahraman S, Yildirim B. An overview of critical thinking in nursing and education. Am Int J of Contemp Res. [Internet]. 2011[Acesso 28 Jun 2015];1(2):1906. Disponível em: http://www.aijcrnet.com/journals/ Vol_1_No_2_September_2011/25.pdf.

10. Paul SA. Assessment of critical thinking: a Delphi study. Nurse Educ Today. [Internet]. 2014 [Acesso 28 Jun 2015]; 34(11):1357-60. Disponível em: http://www.sciencedirect.com/science/ article/pii/S0260691714000811. DOI: 10.1016/j. nedt.2014.03.008. Epub 2014 Mar 25.

11. Becerril LC, Gomez MAJ, Püschel VAA, Fierros GA, Porras MDB, Isaacs LG, et al. Enseñanza y aprendizaje del pensamiento reflexivo y crítico en estudiantes de enfermería en Iberoamérica. México: Cigome; 2014.

12. Jensen R, Cruz DALM, Tesoro MG, Lopes MHBM. Translation and cultural adaptation for Brazil of the Developing Nurses' Thinking model. Rev. LatinoAm. Enfermagem. [Internet]. 2014 [Acesso 28 Jun 2015];22(2):197-203. Disponível em: http://www. ncbi.nlm.nih.gov/pmc/articles/PMC4292602/. DOI: 10.1590/0104-1169.3232.2402.

13. Rodgers BL. Concept analysis: An evolutionary view. In Rodgers BL, Knafl KA. Concept development in nursing: foundations, techniques, and applications. Saunders. 2nd Ed. Philadelphia: Saunders; 2000. p. 77102.

14. Marconi MA, Lakatos EM. Fundamentos de metodologia científica. 7a ed. São Paulo: Atlas; 2010.

15. Cerullo JASB, Cruz DALM. Clinical reasoning and critical thinking. Rev. Latino-Am. Enfermagem. [Internet]. 2010 [Acesso 28 Jun 2015];18(1):124-9. Disponível em: http://www.scielo.br/pdf/rlae/v18n1/19. pdf.

16. Chan ZCY. Critical thinking and creativity in nursing: Learners' perspectives. Nurse Educ Today. [Internet]. 2013 [Acesso 26 Jul 2015];33(5):558-63. Disponível em: http://www.sciencedirect.com/science/ article/pii/S0260691712002894.

DOI: $10.1016 / j$. nedt.2012.09.007. Epub 2012 Oct 9.

17. Bittencourt GKGD, Crossetti MGO. Critical thinking skills in the nursing diagnosis process. Rev Esc Enferm USP. [Internet]. 2013 Apr [Access 2015 Nov 03] ; 47(2): 341-347. Disponível em: http://www. scielo.br/scielo.php?script=sci_arttext $\&$ pid $=$ S0080$62342013000200010 \&$ Ing $=e n \& n r m=i s o \& t \mid n g=e n$.

18. Turner P. Critical thinking in nursing education and practice as defined in the literature. Nurs Educ Perspect. 2005 [Acesso 28 Jun 2015];26(5):272-7. Disponível em: http://web.b.ebscohost.com/ehost/pdfviewer/ pdfviewer?vid=2\&sid=909449f2-b07f-42b9-86efa4268f58fb44\%40sessionmgr115\&hid $=125$.

19. Brunt BA. Critical thinking in nursing: an integrated review. J Contin Educ Nurs. 2005 [Acesso 28 Jun 2015];36(2):60-7. Disponível em: http://web.b.ebscohost.com/ehost/pdfviewer/ pdfviewer?sid=909449f2-b07f-42b9-86ef-a4268f58fb4 $4 \% 40$ sessionmgr115\&vid=5\&hid $=125$.

20. Bittencourt GKGD, Crossetti MGO. Critical Thinking skills in the nursing diagnosis process. Rev Esc Enferm USP. [Internet]. 2013 [Acesso 26 Jul 2015];47(2):3417. Disponível em: http://www.scielo.br/pdf/reeusp/ v47n2/en_10.pdf.

21. Naber J, Wyatt TH. The effect of reflective writing interventions on the critical thinking skills and dispositions of baccalaureate nursing students. Nurse Educ Today. [Internet]. 2014 [Acesso 3 Nov 2015];34(1):67-72. Disponível em: http://www.sciencedirect.com/science/ article/pii/S0260691713001251.

22. Facione PA. Critical thinking: A statement of expert consensus for purposes of educational assessment and instruction. [Internet]. Millbrae: The California Academic Press; 1990 [Acesso 26 Jul 2015]. Disponível em: https://assessment.trinity.duke.edu/documents/ Delphi_Report.pdf.

23. Crossetti MGO, Bittencourt GKGD, Lima AAA, Góes MGO, Saurin G. Structural elements of critical thinking of nurses in emergency care. Rev Gaucha Enferm. 2014 [Acesso 28 Jun 2015];35(3):55-60. Disponível em: http://www.scielo.br/pdf/rgenf/v35n3/19831447-rgenf-35-03-00055.pdf. DOI: http://dx.doi. org/10.1590/1983-1447.2014.03.45947

24. Martyn J, Terwijn R, Kek MYCA, Huijser H. Exploring the relationships between teaching, approaches to learning and critical thinking in a problem-based learning foundation nursing course. Nurse Educ Today. [Internet]. 2014 [Acesso 26 Jul 2015];34(5):829-35. Disponível em: http://www.sciencedirect.com/science/ article/pii/S0260691712002894. DOI: $10.1016 / \mathrm{j}$. nedt.2013.04.023. Epub 2013 May 22.

25. Ministério da Saúde (BR), Conselho Nacional de Educação, Câmara de Educação Superior. Resolução CNE/ CES no 3, de 7 de novembro de 2001: institui Diretrizes Curriculares Nacionais do Curso de Graduação em Enfermagem [Internet]. Brasília (DF); 2001 [Acesso 26 Abr 2015]. Disponível em: http://portal.mec.gov. br/ cne/arquivos/pdf/CES03.pdf. 
26. Pucer $P$, Trobec I, Zvanut B. An information communication technology based approach for the acquisition of critical thinking skills. Nurse Educ Today. [Internet]. 2014 [Acesso 26 Jul 2015];34(6):964-70. Disponível em: http://www.sciencedirect.com/science/ article/pii/S0260691714000379. DOI: $10.1016 / \mathrm{j}$. nedt.2014.01.011. Epub 2014 Feb 14.

27. Carley A. Using technology to enhance nurse practitioner student engagement. Nurse Pract. 2015 [Acesso 28 Jun 2015];40(7):47-54. Disponível em: http://web.b.ebscohost.com/ehost/detail/ detail ? vid $=4 \&$ sid $=88468906-2$ b0a-487b-a95f-d3ed48a $8095 \mathrm{a} \% 40$ sessionmgr120\&hid $=125 \&$ bdata $=$ Jmxhbmc9 cHQtYnImc2I0ZT1laG9zdC1saXZI\#AN=109812615\&db= $\mathrm{C} 8 \mathrm{~h}$

28. Pitt V, Powis D, Levett-Jones T, Hunter S. The influence of critical thinking skills on performance and progression in a pre-registration nursing program. Nurse Educ Today. [Internet]. 2015 [Acesso 03 Nov 2015];35(1):125-131. Disponível em: http://www.sciencedirect.com/science/ article/pii/S026069171400269X?np=y.

29. Siqueira VTA, Kurcgant P. Job Satisfaction: a quality indicator in nursing human resourse management. Rev Esc Enferm USP. [Internet]. 2012 [Acesso 26 Jul 2015];46(1):151-7. Disponível em: http://www.scielo. br/pdf/reeusp/v46n1/en_v46n1a21.pdf. Creative Commons (CC BY).

This license lets others distribute, remix, tweak, and build upon your work, even commercially, as long as they credit you for the original creation. This is the most accommodating of licenses offered. Recommended for maximum dissemination and use of licensed materials. 